\title{
Social Ecological Model of Problem Gambling: A Cross-National Survey Study of Young People in the United States, South Korea, Spain, and Finland
}

\author{
Atte Oksanen ${ }^{1, *} \mathbb{0}$, Anu Sirola ${ }^{2}$, Iina Savolainen ${ }^{1}{ }^{\oplus}$, Aki Koivula $^{3}$, Markus Kaakinen ${ }^{4}$, Ilkka Vuorinen ${ }^{1}{ }^{(}$, \\ Izabela Zych ${ }^{5}$ (i) and Hye-Jin Paek ${ }^{6}$ \\ 1 Faculty of Social Sciences, Tampere University, 33014 Tampere, Finland; iina.savolainen@tuni.fi (I.S.); \\ ilkka.vuorinen@tuni.fi (I.V.) \\ 2 Department of Social Sciences and Philosophy, University of Jyväskylä, 40014 Jyväskylä, Finland; \\ anu.r.s.sirola@jyu.fi \\ 3 Department of Social Research, University of Turku, 20500 Turku, Finland; akjeko@utu.fi \\ 4 Institute of Criminology and Legal Policy, University of Helsinki, 00014 Helsinki, Finland; \\ markus.kaakinen@helsinki.fi \\ 5 Department of Psychology, University of Córdoba, 14004 Córdoba, Spain; izych@uco.es \\ 6 Department of Advertising and Public Relations, Hanyang University, Ansan 15588, Korea; \\ hjpaek@gmail.com \\ check for \\ * Correspondence: atte.oksanen@tuni.fi; Tel.: +358-503187279
} updates

Citation: Oksanen, A.; Sirola, A.; Savolainen, I.; Koivula, A.; Kaakinen, M.; Vuorinen, I.; Zych, I.; Paek, H.-J. Social Ecological Model of Problem Gambling: A Cross-National Survey Study of Young People in the United States, South Korea, Spain, and Finland. Int. J. Environ. Res. Public Health 2021, 18, 3220. https:// doi.org/10.3390/ijerph18063220

\section{Academic Editors:}

Anders Håkansson and Susana Jiménez-Murcia

Received: 27 January 2021

Accepted: 16 March 2021

Published: 20 March 2021

Publisher's Note: MDPI stays neutral with regard to jurisdictional claims in published maps and institutional affiliations.

Copyright: (C) 2021 by the authors Licensee MDPI, Basel, Switzerland. This article is an open access article distributed under the terms and conditions of the Creative Commons Attribution (CC BY) license (https:// creativecommons.org/licenses/by/ $4.0 /)$.

\begin{abstract}
Problem gambling among young people is an emerging trend globally. The online environment in particular offers various possibilities for gambling engagement. This is the first cross-national survey study using the social ecological model to analyze problem gambling, especially in the online context. The study aimed to analyze how different social ecological spheres explain problem gambling. Participants were young people aged $15-25$ in the United States $(n=1212)$, South Korea $(n=1192)$, Spain $(n=1212)$, and Finland $(n=1200)$. The South Oaks Gambling Screen (SOGS) instrument measured problem gambling. The regression models analyzed problem gambling with measures of intrapersonal, interpersonal, organizational, and societal spheres. Spanish participants had the highest SOGS score for problem gambling. In all countries, the variations in problem gambling were best explained by the organizational sphere measures $(26 \%)$ when compared to the intrapersonal (11\%), interpersonal (5\%), and societal (3\%) spheres. In the full model, the organizational sphere measures had strong associations with problem gambling. These included consumer debt, online gambling community participation, online casino participation, and exposure to online popup advertisements. Problem gambling was also associated with conformity to group norms in the interpersonal sphere, and male gender and impulsivity in the intrapersonal sphere. Cross-national results were similar in different countries. Within the final model, gambling community participation had the strongest association with problem gambling $(\beta=0.23, p<0.001)$. The online context plays a major role in problem gambling behavior. The social ecological model is a useful tool for tackling problem gambling and developing preventative measures.
\end{abstract}

Keywords: pathological gambling; social ecological model; adolescents; emerging adults; Internet; online communities; online casinos; consumer debt; advertising; impulsivity

\section{Introduction}

Problems caused by excessive gambling are a global concern [1-3]. Gambling behavior ranges from a harmless pastime activity to at-risk gambling that may develop into more serious forms of problem gambling and become pathological, thus creating negative psychological, social, and financial consequences for individuals, families, and society [4-7]. Currently, gambling and gaming increasingly take place online [8-10] and mainstream social media sites expose users to gambling content and activities [11-13]. Young people 
are the most active users of the Internet and social media sites and hence are at particular risk [14].

Due to the rapidly changing online environment, major gaps exist in research. Few studies have aimed to understand the behavioral and situational factors affecting gambling behavior and the development of gambling problems. This cross-national survey study used a social ecological model of gambling problems to analyze problem gambling among young people, aged 15 to 25 .

\subsection{Social Ecological Model for Gambling Problems}

The need for understanding different types of human behavior social contexts is grounded in social psychology. Out of the classics of social psychology, Kurt Lewin, for example, postulated the classic equation $B=f(P, E)$, noting that behavior is a function of a person and their environment [15]. This has been-and continues to serve as—a starting point for various social ecological models aimed at understanding human behavior from a holistic framework.

The most well-known example of a social ecological theory is Urie Bronfennerbrenner's ecological systems theory of child development that analyzes wellbeing by using overlapping micro-, meso-, exo-, and macrosystems [16-18]. Later on, he also added a chronosystem reflecting time as a context [19]. Bronfenbrenner's core idea is that human development takes place within these ecological systems. His theory and ideas have been widely applied in various social ecological models that share the idea that nested levels or spheres influence human behavior. The model generally has had a major influence on health promotion [20].

Bronfenbrenner's work has also been applied in addiction research. The social ecological framework has been used in investigations of e-cigarette use [21], alcohol consumption [22,23], substance use [24-26], and high-risk sexual behavior [27], but less so in gambling. The only notable exception is a study using the Canadian Adolescent Gambling Inventory. The study used the social ecological model as a starting point but did not further assess the model's usability [6]. Another research gap involves the Internet as a social ecological sphere. The social ecological framework has not been used in addiction research to understand the growing influence of the Internet on behavior. More work has been conducted in other fields, and the social ecological framework's usefulness applied to the online context has been demonstrated in research on bullying [28].

Research on gambling problems has begun to search for comprehensive frameworks encompassing individual, social, and societal factors [29-31]. The Conceptual Framework of Harmful Gambling (CFHG) $[29,30]$ emphasizes that gambling behavior and gambling harms are affected by general individual-level biological and psychological characteristics, but also by interpersonal relations and cultural factors. According to the CFHG, gambling problems are also shaped by the factors that determine the availability of different gambling environments, gambling types, gambling exposure, and resources available for harm reduction and problem gambling prevention within societies and communities.

Blaszczynski and Nower [4] noted ecological factors in the pathways model of problem and pathological gambling, but the theory only considers ecology as availability. However, addiction theories often simplify human behavior and neglect the the importance of social contexts in behavior. Some of them, such as Orford and West's and others' studies [32,33], comment on the relevance of societal and cultural contexts, but the core ideas are not social ecological. From a more social ecological point of view, addictions are formed only via settings that activate people to carry out certain activities despite their harmfulness [34].

A social ecological model for problem gambling considers the development of gambling problems from the perspective of nested spheres, which combines both individual and situational factors. The spheres are grounded on the general ideas that the social ecological theory provides, indicating that human behavior and development take place in different contexts - from micro to macro-and depend on a person's individual characteristics $[18,19]$. The intrapersonal sphere involves biopsychological factors such 
as age, gender, and personality. The interpersonal sphere also involves an individual's interactions with others. The organizational (i.e., institutional) sphere includes potentially influencing factors available for individuals via social institutions. These meso-type factors include, for example, wider communities, institutional settings, and affordances. The societal sphere represents the macro level and includes public policies and cultural values. These four spheres are presented in Figure 1.

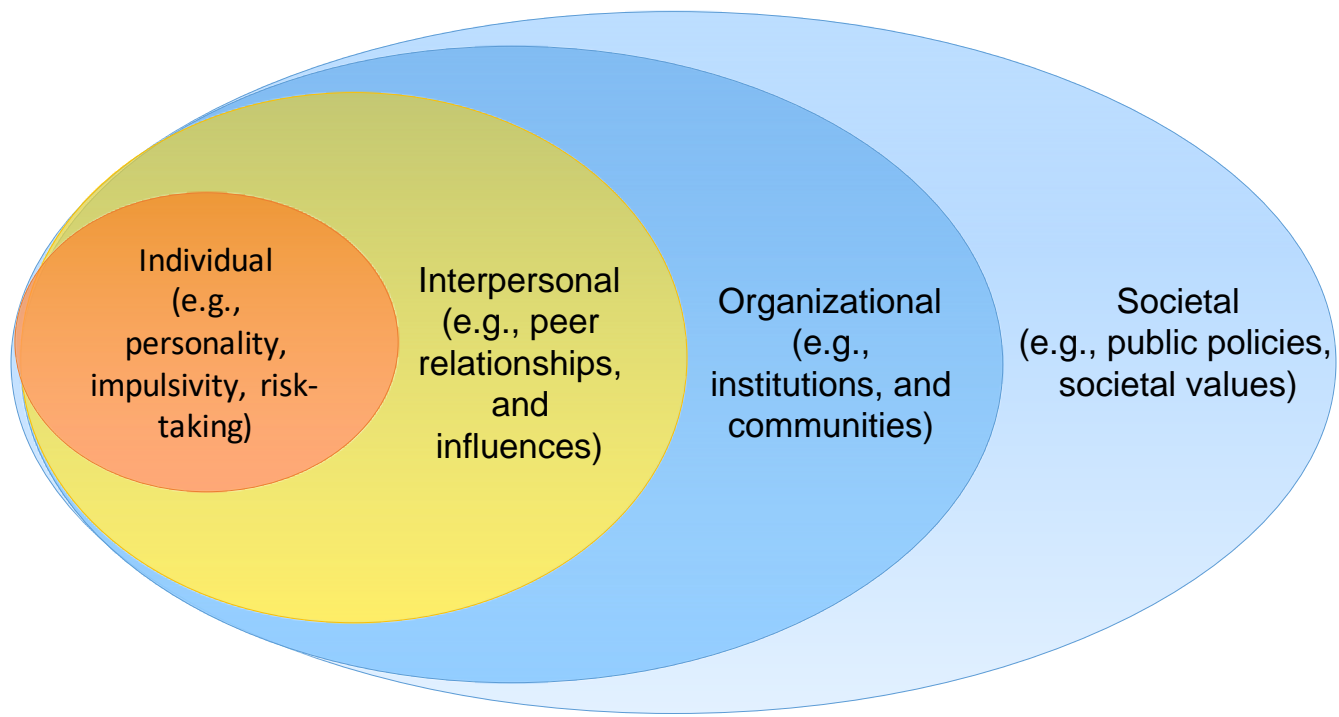

Figure 1. Social ecological model for investigating problem gambling behavior.

\subsection{Evidence on Problem Gambling in Different Spheres}

Research has well established the intrapersonal factors for gambling behavior. Males gamble more than females do in general, and gambling causes more problems for males than it does for females [1,35]. Problem gambling is more common among younger individuals $[1,3]$. Other intrapersonal variables related to personality are also important for understanding problem gambling. For example, impulsivity and sensation seeking are risk factors for problem gambling [35-37]. Similarly, some people are more likely to take risks, which can be associated with problem gambling [37]. Financial risk-taking is also common among young people [38,39]. Research also indicates that people with low self-esteem could be motivated to gamble [40].

Interpersonal factors include people's social ties. In various studies, problem gamblers have reported lower perceived social support [41-43]. In adolescence and young adulthood, optimal relationships with family, peers, teachers, and classmates are important sources of support that protect individuals from problem gambling [44-47]. Although offline social ties provide a protective factor against problem gambling, online social ties involve a risk [47]. Furthermore, especially on social media, people easily become involved in various social cliques or bubbles [14,48] that could also pose a risk for problem gambling [49]. In addition, conformity to social norms influences gambling behavior $[11,50]$.

Organizational factors include wider infrastructure, institutions, and communities that are not restricted to few individuals. Gambling venues such as online casinos are one example of such institutions. Access to casinos and other gambling content is fast and easy online. Online casinos in particular function both legally and illegally [2,10,51]. Furthermore, gambling communities often focus on sharing gambling tips. These types of communities were considered a risk factor for problem gambling in a previous Finnish study. The study noted that these communities, which young people visit online, most often focused on gambling activities and tips rather than the harm gambling causes or recovery from gambling problems [13].

Other organizational factors also influence gambling behavior. New types of opportunities for money lending and consumer credit, such as instant or payday loans, have been 
considered a major risk for financial difficulties, especially for young people [38,39]. These easy-access loans have also been identified as a problem in gambling research [52,53]. These loans occur via the Internet, and they are heavily marketed to users. Studies have also recognized the wide existence and ubiquity of online gambling marketing and advertising [54-56]. Moreover, problem gamblers receive more gambling advertisements, which likely increases their gambling $[57,58]$. Currently, online marketing offers more targeting and customization than ever, and problem gamblers likely receive advertisements about both gambling opportunities and instant loans on their social media feed. Problem gamblers often operate in a bubble [49], and escaping such a bubble is very difficult when marketing algorithms constantly target them with gambling advertisements.

The societal sphere is grounded in the idea of societies or broader unions (e.g., the EU) as macrosystems that influence people's daily lives. This involves legislation in particular, but cultural and societal factors also play a role. For example, socioeconomic contexts, such as area-level income inequality and relative deprivation, contribute to youth problem gambling [44]. On the country level, expenditure on public health plays a role in youth problem gambling [45]. Globally, the prevalence of problem gambling ranges from $0 \%$ to $6 \%$ [1]. Figures also vary by definitions and measures used [59]. Cross-national studies indicate that the prevalence of problem gambling among young people varies between and within countries. For example, King and colleagues' [60] review showed that the problem gambling rate among adolescents in the United States ranged from 1.7\% to 33.8\%, depending on the measure used [60]. Additionally, a recent ESPAD study showed that problem gambling among 16-year-olds ranged from 1.3\% to $12 \%$ in European countries [61]. Given these types of inconsistencies in problem gambling research, it is important to use a cross-national approach when further analyzing the problem gambling phenomenon and its background factors. Moreover, cross-national research should go beyond simple comparisons of problem gambling prevalence rates, which are vulnerable to sampling and measuring differences.

\subsection{This Study}

This is the first cross-national survey study using a social ecological model to analyze problem gambling. Our study was grounded in a cross-national comparison between countries that are societally and culturally different: The United States, South Korea, Spain, and Finland.

The United States is a liberal market-orientated country and South Korea is a technologically advanced East Asian country. Spain and Finland are part of the European Union but very different both culturally and societally. Finland represents a Nordic welfare state and Spain represents the South European regime [62,63]. Culturally, these countries also represent different areas on the Inglehart-Welzel world cultural map and are clearly distinct as societies $[64,65]$. Self-expression values are highest in Finland. Furthermore, Finland and South Korea score highly on secular-rational values in comparison to Spain and the United States in the cultural map [64,65]. The countries also differ in terms of collectivism, South Korea and Spain representing more collectivistic cultures than the United States and Finland $[66,67]$. The main similarity between our focus countries was that young people in all of these locations engaged actively on the Internet and social media [68].

In the United States, gambling is largely legalized and visible. Although federal legislations exist, each state holds its own laws and regulations for gambling, and the legal gambling age ranges from 18 to 21 in the country [69]. Although Finland and Spain are part of the EU, they regulate gambling nationally. Finland has a national monopoly system that the Lotteries Act regulates. Gambling services in Finland are provided solely by Veikkaus Oy, which is a state-owned company [70]. The legal gambling age limit in Finland is 18 years. In Spain, gambling is regulated on a national level by the Ministry of Consumption Gambling Act. The Directorate General for the Regulation of Gambling is the state-level authority that manages the regulations, licensing, and sanctioning of gambling activities. All gambling operators must attain a proper license for the operation, 
and individuals under the age of 18 are prohibited from gambling [71]. South Korea differs from the other three countries due to its significantly stricter gambling legislation. The National Gambling Commission Act regulates the gaming industry in South Korea, with the National Gambling Control Commission (NGCC) operating as its regulatory body. The NGCC controls the number of gambling businesses in the country as well as media content so that advertising is not released that may inspire excessive gambling. Limited gambling activities are legal and accessible for Koreans older than 18 years of age, as Korean citizens are only allowed to gamble in one of its casinos and participate in legal sports betting or lotteries $[72,73]$.

Gambling is prevalent in all four countries. A review report found that the standardized problem gambling prevalence among the adult population was $1.5 \%$ in the United States (2001-2003), 1.5\% in Finland (2011), 0.8\% in South Korea (2011), and between 1.0\% and $1.6 \%$ in different regions of Spain [73]. Problem gambling is visible even among young individuals. According to the ESPAD study, 3.9\% of Finnish and 3.2\% of Spanish 16-yearolds are problem gamblers [61]. National investigations in both countries also showed high figures. For example, in Finland, 5.3\% of 18-24-year-olds reported problem gambling in 2019, according to the National Institute of Health and Welfare's annual report [74]. Some recent reports from Spain have indicated relatively high figures of problem gambling as well. For instance, recent findings reported the rate of pathological gambling among 14- to 18 -year-old youths is $7.6 \%$ for boys and $2 \%$ for girls [75]. However, samples, measures, and definitions vary from research to research [76-78]. In the U.S., a meta-analysis based on research on 13,000 college students estimated that $10.2 \%$ of them were probable pathological gamblers [79]. In a national sample from the United States, the prevalence of problem gambling was 5.4\% among 18- to 30-year-olds [69]. A study conducted on South Korean college students found that, out of the sample used, $8.6 \%$ qualified as problem gamblers [80]. The results reflected the findings of previous prevalence research on problem gambling among South Korean college students with rates ranging from $11 \%$ to $14.6 \%$ [81]. In a national study, problem gambling prevalence was $3.4 \%$ for those aged 18 to 30 [82].

The country selection gave this study an excellent starting point because it enabled us to estimate the functionality of the social ecological model in different societal settings. The study focused on the online context and young people aged 15 to 25 . Our starting point was to test the usability of a social ecological model for cross-national research and to analyze how well intrapersonal, interpersonal, organizational, and societal spheres explain problem gambling. Our hypotheses were grounded generally in the social ecological model of problem gambling and previous research on problem gambling; we expected that intrapersonal, interpersonal, and organizational factors would be associated with problem gambling. Exact variable-specific hypotheses were not preregistered due to the lack of previous studies using the social ecological model cross-nationally. Differences between countries were also investigated, but due to lack of previous research, we did not make any hypotheses for these differences.

\section{Materials and Methods}

\subsection{Participants and Procedure}

Our empirical evidence is based on cross-national survey data collected from 4816 young people aged 15 to 25 in Finland ( $n=1200,50.0 \%$ male), the United States $(n=1212$, $49.83 \%$ female), South Korea ( $n=1192,49.58 \%$ male), and Spain ( $n=1212,51.24 \%$ male). The mean age of the participants was $21.29(\mathrm{SD}=2.85)$ in Finland, $20.05(\mathrm{SD}=3.19)$ in the United States, $20.61(\mathrm{SD}=3.24)$ in South Korea, and $20.07(\mathrm{SD}=3.16)$ in Spain. Of the participants, $58.85 \%$ were living with their parents $\left(35.92 \%_{\mathrm{FIN}}, 51.16 \%_{\mathrm{US}}, 81.80 \%_{\mathrm{SK}}\right.$, $\left.66.67 \%_{\text {SPA }}\right), 61.00 \%$ were students $\left(64.33 \%_{\text {FIN }}, 53.96 \%_{\text {US }}, 67.53 \%_{\text {SK }}, 58.33 \%\right.$ SPA $), 22.57 \%$ had a university degree $\left(13.42 \%_{\mathrm{FIN}}, 20.38 \%_{\mathrm{US}}, 28.10 \%_{\mathrm{SK}}, 28.38 \%_{\mathrm{SPA}}\right)$, and $5.38 \%$ were born abroad $\left(4.08 \%_{\text {FIN }}, 4.54 \%_{\text {US }}, 0.59 \%_{\text {SK }}, 12.21 \%_{\text {SPA }}\right)$. See Table A1 in Appendix A for more information on the samples. 
Data were collected from Finland in 2017, the United States in 2018, South Korea in 2018, and Spain in 2019 using identical YouGamble surveys focused on gambling, social media use, and wellbeing. Survey languages were Finnish in Finland, English in the United States, Korean in South Korea, and Spanish in Spain. The original YouGamble survey was in Finnish and professional-level translators converted it to English. Then, professional-level translators translated the Korean and Spanish surveys from the English version, and we used the back-translation process to confirm the translations' accuracy.

Study participants were recruited using research panels the Survey Sampling International (currently Dynata) offers, which provides data solutions for research purposes globally. Dynata currently holds the largest research panels globally and it is available for different types of research. Such research panels typically have signed on participants who are contacted separately for each survey. Using research panels has become commonplace in social sciences and are considered a good alternative due to the difficulty of accessing hard-to-reach populations such as emerging adults [83]. The online data collection method avoids bias caused by traditional means such as phone surveys, especially when studying gambling problems [84].

The research group administrated all data collection and ran the survey using the Tampere University server. All four YouGamble surveys were collected using LimeSurvey software, and they were optimized for computers and mobile devices. Survey Sampling International sent a survey link to respondents. As our surveys were targeted to American, Finnish, South Korean, and Spanish young individuals in the 15-25 age group representing the general population, no additional inclusion criteria were applied. Sampling quotas were used to ensure the data matched the population of young people aged 15 to 25 in all the countries, especially in terms of age and gender, but also living area. Comparing country samples with the population showed only minor deviations; hence, analytical weights were not applied [52,68,84]. Besides these efforts to check and control the potential sources of bias, we ran additional data integrity checks during data collection on participant inclusion and participant effort $[85,86]$. Some of the full research project hypotheses were also preregistered [11]. Attention checks were run during the survey collection and the respondents who completed the survey excessively fast were not included in the data. We also looked separately for duplicate responses, and ran attention checks for response quality, matched item checks, and performed straight-lining checks. Additionally, we investigated the consistency of scales and sub-scales.

All respondents were volunteers and gave their consent for participation. In Finland, the legal age of consent is 15 years, so no parental consent was required, but it was still attained. Parental consent was also attained for the U.S., South Korean, and Spanish 15-17-year-old participants. All participants were informed about the study and were aware they could withdraw at any time without consequences. All responses were anonymous and no identifying information was collected. The ethics committee of the Tampere region in Finland reviewed the research protocol and stated the research did not include any ethical issues. The median survey response time was $14.54 \mathrm{~min}\left(15.30_{\mathrm{FIN}}, 14.49_{\mathrm{US}}\right.$, $\left.12.32_{\mathrm{SK}}, 16.47_{\mathrm{SPA}}\right)$. The online survey format allowed questions to be mandatory and hence, no data are missing.

\subsection{Measures}

\subsubsection{Problem Gambling}

Problem gambling was the outcome measure of our study, which we measured with the South Oaks Gambling Screen (SOGS). SOGS is among the most used measures for problem gambling $[87,88]$. It has also been used among 15 - to 17 -year-olds [89,90]. The scale had excellent inter-item reliability of 0.88 , based on McDonald's $\Omega$ : $\Omega_{\mathrm{FIN}}=0.89, \Omega_{\mathrm{US}}=0.88$, $\Omega_{\mathrm{SK}}=0.87, \Omega_{\mathrm{SPA}}=0.86$. SOGS reviews gambling activities from the past $12 \mathrm{months}$ and scrutinizes factors indicating potential gambling problems based on 20 scoring items. SOGS scores' range from 0 to 20, and higher scores indicate problem gambling. We used SOGS as a continuous measure in the analysis, but we also report results based on the cutoff of $\geq 8$ 
for disordered gambling. A higher cutoff is considered better due to the potential for false positives with lower cutoffs [91].

\subsubsection{Intrapersonal Sphere}

Besides gender and age measures of the intrapersonal sphere, this study included impulsivity, self-esteem, and risk-taking.

Impulsivity was measured with the Eysenck Impulsivity Scale [36,92], with higher scores indicating higher impulsiveness. Response options were no (0) and yes (1) for all questions. The measure showed acceptable inter-item reliability: $\Omega=0.69\left(\Omega_{\mathrm{FIN}}=0.75\right.$, $\Omega_{\mathrm{US}}=0.70, \Omega_{\mathrm{SK}}=0.64, \Omega_{\mathrm{SPA}}=0.67$ ). In addition, the polychoric ordinal alpha coefficients for inter-item reliability of dichotomous scale were adequate: $\alpha_{\text {FIN }}=0.87, \alpha_{\mathrm{US}}=0.81$, $\alpha_{\mathrm{SK}}=0.77 \alpha_{\mathrm{SPA}}=0.80$.

Self-esteem was measured with a single-item self-esteem scale [93]. Participants responded to the statement "I have high self-esteem" on a scale from 1 (not very true of me) to 10 (very true of me).

Risk-taking was measured with a single-item statement ("I enjoy taking risks"), which was adapted from the 1979 National Longitudinal Survey of Youth (NLSY79) [94] and widely validated in various studies [95]. Response options ranged from 1 (not very true of me) to 10 (very true of me).

\subsubsection{Interpersonal Sphere}

Interpersonal sphere measures included perceived social support, sense of belonging offline and online, involvement in social media identity bubbles, and conformity to group norms. These measures reflect individuals' behavior in their close relationships and intimate groups.

Perceived social support was measured with a single item: "Do you feel that you receive support from your close ones when you need it?" The answer options were "never", "sometimes", and "often". The options were categorized into a dummy variable indicating high social support $(0=$ never or sometimes, $1=$ often $)$.

Offline belonging was measured with three items to indicate how strongly respondents felt they belonged to their close family members, friends, and school or work peers. All three items had response options ranging from 1 (not at all) to 10 (very strongly). The scale showed good inter-item reliability: $\Omega=0.79\left(\Omega_{\mathrm{FIN}}=0.77, \Omega_{\mathrm{US}}=0.83, \Omega_{\mathrm{SK}}=0.82\right.$, $\left.\Omega_{\mathrm{SPA}}=0.76\right)$. The scale was adjusted to a range of 1 to 10 . A similar measure was used for online belonging. It asked how strongly participants felt they belonged to an online community [49]. Responses ranged from 1 (not at all) to 10 (very strongly).

We used the six-item Identity Bubble Reinforcement Scale (IBRS-6) to measure involvement in social media identity bubbles (i.e., social cliques) [48]. The scale consisted of items such as "On social media, I belong to a community or communities that are important parts of my identity" rated from 1 (does not describe me at all) to 10 (describes me completely). The IBR-6 had high inter-item reliability: $\Omega=0.88\left(\Omega_{\mathrm{FIN}}=0.79, \Omega_{\mathrm{US}}=0.90, \Omega_{\mathrm{SK}}=0.93\right.$, $\left.\Omega_{\mathrm{SPA}}=0.86\right)$. The scale was adjusted to range from 1 to 10 .

Conformity to group norms was also included in the interpersonal sphere. This measure was based on an online experiment included in the middle of the survey [11]. The experiment simulated a social media setting and showed respondents gambling messages they could either like (thumbs up), dislike (thumbs down), or ignore. In the style of messages on social media, they were shown how other people had reacted to the same message. Numbers of likes and dislikes presented as reactions from other participants were manipulated in the experiment. Different gambling messages were shown four times. The scale ranged from 0 to 4 , indicating the number of times respondents had agreed with the majority of others (i.e., selected the same response as about $85 \%$ of the other respondents). A higher score indicated higher conformity with the group norm. The scale had good inter-item reliability: $\Omega=0.79\left(\Omega_{\mathrm{FIN}}=0.76, \Omega_{\mathrm{US}}=0.78, \Omega_{\mathrm{SK}}=0.82, \Omega_{\mathrm{SPA}}=0.72\right)$. 


\subsubsection{Organizational Sphere}

Organizational sphere measures included consumer debt, participation in online casinos, participation in online gambling communities, and exposure to online pop-up gambling advertisements. These were related to institutions and considered wider than interpersonal factors.

Participants in all of the countries were asked whether they had taken payday loans or consumer debt in the past. In the Finnish survey, respondents were asked, "Have you ever taken instant loans, payday loans, or consumer credit?" Answer options were yes or no. These were categorized into a dummy variable: $0=$ no consumer debt and $1=$ consumer debt. In other surveys, respondents were asked whether they had taken a loan and then specified the type of loan taken: personal loans, consumer or credit card loans, cash advance loans, and payday loans were categorized as consumer debt. A dummy variable was created: $0=$ no consumer debt, $1=$ consumer debt.

Online casino participation was measured with the question: "How often do you use online casino sites or other sites by gambling companies?" The answer options were "never", "seldom", "daily", or "many times a day". The answers were categorized into a dummy variable: $0=$ no (never) and $1=$ yes (at least seldom).

Online gambling community participation was measured with the question: "How often do you use gambling-related discussion forums or communities?" The answer options were "never", "seldom", "daily", or "many times a day", and the response options were categorized into a dummy variable: $0=$ no (never) and $1=$ yes (at least seldom). Those who had participated in such communities were also asked a multiple-choice question on the content of such communities with the options of "gambling tips", "users' gambling experiences", "gambling problems and recovery", "gambling in general", and "other issues". The respondents were able to select multiple options.

Exposure to pop-up gambling advertisements was measured with the question: "Have you received online advertisements or announcements related to gambling (e.g., advertising messages from online casinos or pop-up windows)?" The answer options ranged from never to daily. Options were categorized into never, monthly (several times a month or less), or weekly (once a week or more often).

\subsubsection{Societal Sphere}

The societal sphere in our cross-national investigation refers to the four countries' societal spheres at the national level; hence, in this study, the societal sphere only reflects the macro level.

\subsection{Statistical Modelling}

Statistical analyses were run with Stata 16.1 software. The article reports descriptive results in Table 1 and the accompanying text. We used the $\chi^{2}$ test for the descriptive results. The main analyses focus on the regression models investigating how different social ecological spheres were associated with problem gambling in the four countries. We chose linear regression for the main method of estimating how well different spheres predicted gambling problems due to the comparability of results. We report standardized beta coefficients $(\beta)$ that equal the correlation between the predictors and the outcome variable, which are comparable across models. In addition, coefficients of determination $\left(R^{2}\right)$ and $p$ values for statistical significance are reported. Models are reported both separately for each country and by using aggregated data $(N=4816)$. Besides the regression coefficients, we also report partial eta squared $\left(\eta^{2} p\right)$ effect sizes in the text. 
Table 1. Descriptive statistics of study variables.

\begin{tabular}{|c|c|c|c|c|c|c|}
\hline & & Finland & United States & South Korea & Spain & All \\
\hline Dependent variable & Scale & $\mathrm{M} / \%$ & $\mathrm{M} / \%$ & $\mathrm{M} / \%$ & $\mathrm{M} / \%$ & $\mathrm{M} / \%$ \\
\hline $\begin{array}{c}\text { Problem gambling (SOGS) } \\
\text { Independent variables }\end{array}$ & $\begin{aligned} & 0-20 \\
\geq & 8 \text { points }\end{aligned}$ & $\begin{array}{c}1.59 \\
3.67 \%\end{array}$ & $\begin{array}{c}1.26 \\
3.63 \%\end{array}$ & $\begin{array}{c}0.73 \\
1.76 \%\end{array}$ & $\begin{array}{c}1.81 \\
6.27 \%\end{array}$ & $\begin{array}{c}1.35 \\
3.84 \%\end{array}$ \\
\hline Intrapersonal & Scale & $\mathrm{M} / \%$ & $\mathrm{M} / \%$ & $\mathrm{M} / \%$ & $\mathrm{M} / \%$ & $\mathrm{M} / \%$ \\
\hline $\begin{array}{l}\text { Gender (male) } \\
\text { Age } \\
\text { Impulsivity } \\
\text { Self-esteem } \\
\text { Risk-taking }\end{array}$ & $\begin{array}{c}\mathrm{F} / \mathrm{M} \\
15-25 \\
0-5 \\
1-10 \\
1-10\end{array}$ & $\begin{array}{c}50.00 \% \\
21.29 \\
1.96 \\
5.99 \\
5.12\end{array}$ & $\begin{array}{c}49.83 \% \\
20.05 \\
1.90 \\
6.04 \\
5.74\end{array}$ & $\begin{array}{c}49.58 \% \\
20.61 \\
1.56 \\
5.81 \\
4.21\end{array}$ & $\begin{array}{c}51.24 \% \\
20.07 \\
2.05 \\
6.10 \\
5.41\end{array}$ & $\begin{array}{c}50.17 \% \\
20.50 \\
1.87 \\
5.99 \\
5.12\end{array}$ \\
\hline Interpersonal & Scale & $\mathrm{M} / \%$ & $\mathrm{M} / \%$ & $\mathrm{M} / \%$ & $\mathrm{M} / \%$ & $\mathrm{M} / \%$ \\
\hline $\begin{array}{l}\text { Perceived social support (high) } \\
\text { Belonging offline } \\
\text { Belonging online } \\
\text { Social media identity bubble } \\
\text { Conformity to group norms }\end{array}$ & $\begin{array}{c}\text { low / high } \\
1-10 \\
1-10 \\
1-10 \\
0-4\end{array}$ & $\begin{array}{c}52.92 \% \\
6.73 \\
5.04 \\
4.63 \\
1.27\end{array}$ & $\begin{array}{l}41.34 \% \\
6.78 \\
5.38 \\
5.96 \\
1.66\end{array}$ & $\begin{array}{c}23.07 \% \\
6.69 \\
4.38 \\
5.26 \\
1.67\end{array}$ & $\begin{array}{c}48.76 \% \\
7.11 \\
4.91 \\
5.75 \\
1.79\end{array}$ & $\begin{array}{l}41.57 \% \\
6.83 \\
4.93 \\
5.40 \\
1.60\end{array}$ \\
\hline Organizational & Scale & $\%$ & $\%$ & $\%$ & $\%$ & $\%$ \\
\hline $\begin{array}{c}\text { Consumer debt } \\
\text { Online casino participation } \\
\text { Online gambling community participation } \\
\text { Pop-up gambling advertisements }\end{array}$ & $\begin{array}{c}\text { No/yes } \\
\text { No/yes } \\
\text { No/yes } \\
\text { Never } \\
\text { Max monthly } \\
\text { Weekly }\end{array}$ & $\begin{array}{c}12.17 \% \\
42.33 \% \\
14.42 \% \\
9.00 \% \\
59.58 \% \\
31.42 \%\end{array}$ & $\begin{array}{c}9.32 \% \\
18.23 \% \\
13.94 \% \\
27.15 \% \\
53.80 \% \\
19.06 \%\end{array}$ & $\begin{array}{c}5.54 \% \\
8.05 \% \\
7.13 \% \\
37.58 \% \\
49.92 \% \\
12.5 \%\end{array}$ & $\begin{array}{c}8.83 \% \\
28.22 \% \\
25.58 \% \\
8.17 \% \\
53.71 \% \\
38.12 \%\end{array}$ & $\begin{array}{c}8.97 \% \\
24.23 \% \\
15.30 \% \\
20.43 \% \\
54.26 \% \\
25.31 \%\end{array}$ \\
\hline
\end{tabular}

We did not detect problematic multicollinearity. The Breusch-Pagan test for heteroscedasticity showed some problems with heteroscedasticity of residuals, thus we ran the models using robust estimators of variance (i.e., sandwich estimator and Huber-White estimator). We ran additional checks for robustness because outliers were detected by looking at Cook's distance measure, where values greater than $4 / \mathrm{n}$ may cause problems. We report the final model without outliers in Appendix B. In addition, country interactions were tested separately for each variable.

Appendix $B$ also includes an alternative logistic regression model that uses a cutoff of $\geq 8$ for problem gambling. We report odds ratios (ORs), their $95 \%$ confidence intervals, and $p$ values for statistical significance. We also report a zero-inflated negative binomial (ZINB) regression model that takes into account overdispersion and excess zeroes of the outcome variable. ZINB is considered the most consistent model in these circumstances [96]. We ran ZINB models with robust estimation as the statistical literature suggests [97]. ZINB models isolate excess zeroes into a separate binary analysis and report remaining count variable analysis with incidence rate ratios (IRR) that are interpreted similarly to ORs in binary logistic regression (IRR $>1$ indicates higher risk, and IRR $<1$ indicates lower risk). We also report McFadden's pseudo $\mathrm{R}^{2}$ coefficients, but these figures should be interpreted with caution as they are not comparable to linear regression coefficients.

\section{Results}

Descriptive statistics and information about the measures are reported in Table 1. SOGS score was highest among participants from Spain, followed by Finland, the United States, and South Korea. Based on a SOGS cut-off score of $\geq 8,3.84 \%$ of the participants were disordered gamblers. The proportion of disordered gamblers was highest in Spain and lowest in South Korea $\left(\chi^{2}(3, N=4816)=33.56, p<0.001\right)$.

Remarkable differences appeared, especially in the organizational sphere. For example, 42.33\% of Finnish participants have visited online casino sites: $91 \%$ of them had been exposed to pop-up gambling advertisements, and $12.17 \%$ had taken on consumer debt. The figures in South Korea were very low, but participants from Spain and the United States also reported lower figures. 
Online gambling community participation was highest among Spanish participants (25.58\%), but also high among participants from Finland $(14.42 \%)$ and the United States $(13.94 \%)$, and low in South Korea $(7.13 \%): \chi^{2}(3, N=4816)=162.59, p<0.001$. These communities were generally about gambling advice, tips, and experiences from other users, and hence, could be considered pro-gambling communities. Only $20.62 \%$ of the participants had selected gambling problems or gambling problem recovery as topics of such communities.

Table 2 reports the findings of the linear OLS regression investigating the association of problem gambling and intrapersonal, interpersonal, organizational, and societal spheres. Results showed the organizational sphere $(27 \%)$ and intrapersonal sphere $(11 \%)$ best explained the variance of the SOGS score. Interpersonal (5\%) and societal (3\%) spheres were not as strong predictors. Notably, the different spheres' models are very similar in all countries and only minor differences exist among them. All the significant effects have the same direction in all models. Robust predictors of problem gambling include, for example, male gender, impulsivity, risk-taking, conformity to group norms, and gambling community participation, which were statistically significant in all countries.

Table 2. Problem gambling explained by intrapersonal, interpersonal, organizational, and societal spheres in separate linear regression models.

\begin{tabular}{|c|c|c|c|c|c|c|c|c|c|c|}
\hline \multirow[b]{2}{*}{ Intrapersonal } & \multicolumn{2}{|c|}{ Finland } & \multicolumn{2}{|c|}{ United States } & \multicolumn{2}{|c|}{ South Korea } & \multicolumn{2}{|c|}{ Spain } & \multicolumn{2}{|c|}{ All } \\
\hline & $\beta$ & $p$ & $\beta$ & $p$ & $\beta$ & $p$ & $\beta$ & $p$ & $\beta$ & $p$ \\
\hline Male gender & 0.23 & $<0.001$ & 0.14 & $<0.001$ & 0.14 & $<0.001$ & 0.22 & $<0.001$ & 0.18 & $<0.001$ \\
\hline Age & 0.05 & 0.060 & 0.18 & $<0.001$ & -0.06 & 0.073 & 0.15 & $<0.001$ & 0.09 & $<0.001$ \\
\hline Impulsivity & 0.19 & $<0.001$ & 0.21 & $<0.001$ & 0.12 & $<0.001$ & 0.20 & $<0.001$ & 0.19 & $<0.001$ \\
\hline Self-esteem & -0.15 & $<0.001$ & 0.03 & 0.383 & -0.07 & 0.012 & -0.05 & 0.097 & -0.06 & $<0.001$ \\
\hline Risk-taking & 0.11 & 0.002 & 0.10 & $<0.001$ & 0.19 & $<0.001$ & 0.17 & $<0.001$ & 0.16 & $<0.001$ \\
\hline Model adjusted $\mathrm{R}^{2}$ & $12 \%$ & & $11 \%$ & & $8 \%$ & & $15 \%$ & & $11 \%$ & \\
\hline Interpersonal & $\beta$ & $p$ & $\beta$ & $p$ & $\beta$ & $p$ & $\beta$ & $p$ & $\beta$ & $p$ \\
\hline Perceived social support (high) & -0.08 & 0.012 & -0.16 & $<0.001$ & -0.04 & 0.193 & -0.20 & $<0.001$ & -0.09 & $<0.001$ \\
\hline Belonging offline & -0.13 & 0.001 & -0.03 & 0.418 & -0.11 & $<0.001$ & -0.03 & 0.399 & -0.08 & $<0.001$ \\
\hline Belonging online & 0.04 & 0.149 & 0.10 & 0.001 & 0.13 & $<0.001$ & 0.16 & $<0.001$ & 0.13 & $<0.001$ \\
\hline Social media identity bubble & 0.02 & 0.630 & 0.08 & 0.008 & 0.08 & 0.002 & 0.12 & $<0.001$ & 0.07 & $<0.001$ \\
\hline Conformity to group norm & 0.14 & $<0.001$ & 0.10 & $<0.001$ & 0.08 & 0.002 & 0.06 & 0.014 & 0.08 & $<0.001$ \\
\hline Model adjusted $\mathrm{R}^{2}$ & $5 \%$ & & $6 \%$ & & $4 \%$ & & $11 \%$ & & $5 \%$ & \\
\hline Organizational & $\beta$ & $p$ & $\beta$ & $p$ & $\beta$ & $p$ & $\beta$ & $p$ & $\beta$ & $p$ \\
\hline Consumer debt & 0.19 & $<0.001$ & 0.06 & 00.067 & 0.18 & $<0.001$ & 0.10 & 0.004 & 0.12 & $<0.001$ \\
\hline Online casino participation & 0.22 & $<0.001$ & 0.17 & 0.002 & 0.12 & 0.175 & 0.22 & $<0.001$ & 0.20 & $<0.001$ \\
\hline $\begin{array}{l}\text { Online gambling community partic. } \\
\text { Pop-up gambling advertisements } \\
\text { (ref. never) }\end{array}$ & 0.25 & $<0.001$ & 0.26 & $<0.001$ & 0.33 & 0.001 & 0.26 & $<0.001$ & 0.28 & $<0.001$ \\
\hline Max monthly & -0.04 & 0.504 & 0.07 & 0.001 & 0.05 & 0.005 & 0.06 & 0.018 & 0.05 & $<0.001$ \\
\hline Weekly & -0.03 & 0.650 & 0.17 & $<0.001$ & 0.11 & 0.001 & 0.18 & $<0.001$ & 0.13 & $<0.001$ \\
\hline Model adjusted $\mathrm{R}^{2}$ & $22 \%$ & & $23 \%$ & & $29 \%$ & & $26 \%$ & & $26 \%$ & \\
\hline Societal & & & & & & & & & $\beta$ & $p$ \\
\hline $\begin{array}{l}\text { Country difference (ref. Spain) } \\
\text { Finland }\end{array}$ & - & - & - & - & - & - & - & - & -0.04 & 0.049 \\
\hline United States & - & - & - & - & - & - & - & - & -0.09 & 0.000 \\
\hline South Korea & - & - & - & - & - & - & - & - & -0.18 & 0.000 \\
\hline Model adjusted $\mathrm{R}^{2}$ & & & & & & & & & $3 \%$ & \\
\hline
\end{tabular}

Table 3 reports full models for all four countries and the complete aggregated dataset. Male gender, impulsivity, and risk-taking were statistically significant predictors of problem gambling in the intrapersonal sphere. None of the interpersonal sphere measures were significant in any of the countries, and effect sizes were small where significant. Out of the organizational sphere predictors, online gambling community participation was significant in all countries and in the aggregated model. Online casino participation was not significant 
in South Korea but remained significant in all other models even after adjusting for the number of factors.

Table 3. Problem gambling explained by the full social ecological model in linear regression models.

\begin{tabular}{|c|c|c|c|c|c|c|c|c|c|c|}
\hline \multirow[b]{2}{*}{ Intrapersonal } & \multicolumn{2}{|c|}{ Finland } & \multicolumn{2}{|c|}{ United States } & \multicolumn{2}{|c|}{ South Korea } & \multicolumn{2}{|c|}{ Spain } & \multicolumn{2}{|c|}{ All } \\
\hline & $\beta$ & $p$ & $\beta$ & $p$ & $\beta$ & $p$ & $\beta$ & $p$ & $\beta$ & $p$ \\
\hline Male gender & 0.12 & $<0.001$ & 0.08 & 0.001 & 0.08 & $<0.001$ & 0.13 & $<0.001$ & 0.11 & $<0.001$ \\
\hline Age & -0.06 & 0.015 & 0.10 & 0.001 & -0.08 & 0.009 & 0.06 & 0.026 & 0.01 & 0.398 \\
\hline Impulsivity & 0.13 & $<0.001$ & 0.14 & $<0.001$ & 0.04 & 0.102 & 0.13 & $<0.001$ & 0.12 & $<0.001$ \\
\hline Self-esteem & -0.06 & 0.027 & 0.01 & 0.867 & -0.06 & 0.028 & -0.03 & 0.289 & -0.03 & 0.048 \\
\hline Risk-taking & 0.05 & 0.094 & 0.05 & 0.092 & 0.07 & 0.010 & 0.07 & 0.003 & 0.07 & $<0.001$ \\
\hline Interpersonal & & & & & & & & & & \\
\hline Perceived social support (high) & -0.03 & 0.206 & -0.06 & 0.053 & 0.02 & 0.490 & -0.09 & 0.003 & -0.06 & $<0.001$ \\
\hline Belonging offline & -0.07 & 0.029 & -0.01 & 0.864 & -0.04 & 0.236 & -0.02 & 0.596 & -0.04 & 0.030 \\
\hline Belonging online & -0.02 & 0.411 & 0.02 & 0.494 & 0.00 & 0.908 & 0.08 & 0.003 & 0.03 & 0.033 \\
\hline Social media identity bubble & 0.02 & 0.446 & 0.00 & 0.946 & 0.03 & 0.158 & 0.02 & 0.368 & 0.03 & 0.058 \\
\hline $\begin{array}{c}\text { Conformity to group norm } \\
\text { Organizational }\end{array}$ & 0.06 & 0.037 & 0.04 & 0.089 & 0.06 & 0.002 & 0.02 & 0.435 & 0.04 & $<0.001$ \\
\hline Consumer debt & 0.16 & $<0.001$ & 0.03 & 0.352 & 0.18 & $<0.001$ & 0.07 & 0.034 & 0.11 & $<0.001$ \\
\hline Online casino participation & 0.22 & $<0.001$ & 0.14 & 0.011 & 0.11 & 0.214 & 0.16 & $<0.001$ & 0.17 & $<0.001$ \\
\hline $\begin{array}{l}\text { Online gambling comm. partic. } \\
\text { Pop-up gambling advertisements } \\
\text { (ref. never) }\end{array}$ & 0.20 & $<0.001$ & 0.23 & $<0.001$ & 0.31 & 0.002 & 0.21 & $<0.001$ & 0.23 & $<0.001$ \\
\hline Max monthly & -0.02 & 0.739 & 0.04 & 0.045 & 0.03 & 0.106 & 0.04 & 0.205 & 0.02 & 0.073 \\
\hline $\begin{array}{l}\text { Weekly } \\
\text { Societal }\end{array}$ & -0.02 & 0.790 & 0.13 & $<0.001$ & 0.09 & 0.008 & 0.13 & $<0.001$ & 0.09 & $<0.001$ \\
\hline $\begin{array}{c}\text { Country difference (ref. Spain) } \\
\text { Finland }\end{array}$ & - & - & - & - & - & - & - & - & -0.01 & 0.446 \\
\hline United States & - & - & - & - & - & - & - & - & -0.03 & 0.056 \\
\hline South Korea & - & - & - & - & - & - & - & - & -0.05 & 0.004 \\
\hline Model adjusted $\mathrm{R}^{2}$ & $28 \%$ & & $27 \%$ & & $31 \%$ & & $33 \%$ & & $31 \%$ & \\
\hline
\end{tabular}

Gambling community participation had the strongest correlation with gambling problems $(\beta=0.23)$. The age-, gender-, and country-adjusted effect size of online gambling community participation was large in all countries and in the aggregated model $\left(\eta^{2} p=0.20\right)$. Online casino participation also had relatively large effect sizes. In Finland, the association of online casino participation and problem gambling was strongest $(\beta=0.23$, age- and gender-adjusted $\eta^{2} p=0.11$ ). In addition, consumer debt was statistically significant in all the countries except the United States. Similarly, those who were exposed to pop-up gambling advertisements on a weekly basis reported higher problem gambling than others in all the countries except Finland. The full model that controlled all the spheres only showed a statistically significant difference between Spain and South Korea.

We ran robustness analyses first with linear regression by omitting outliers (see Table A2 in Appendix B). The model $(n=4546)$ explained 38\% of the variance of problem gambling. The results were very consistent with the previous models, except some coefficients were higher, such as online gambling community participation $(\beta=0.28, p<0.001)$. The robustness of our findings was further verified by running analyses with logistic regression and ZINB regression. These findings showed male gender, high impulsivity, and low self-esteem predicted problem gambling. In addition, consumer debt, online casino participation, online gambling community participation, and weekly exposure to pop-up gambling advertisements were associated with problem gambling. These findings generally underline the relevance of both the intrapersonal and organizational spheres in explaining problem gambling behavior.

Further country differences were analyzed with country interactions in the full linear model $(N=4816)$ with significant predictors. No differences occurred between women among the countries, but Spanish males had higher problem gambling than males in the United States $(\beta=0.05, p=0.042)$ and South Korea $(\beta=0.06, p=0.005)$. Impulsivity was not as strongly associated with problem gambling in South Korea as it was in Spain $(\beta=-0.19, p=0.001)$. Exposure to pop-up gambling advertisements was not associated 
with problem gambling in Finland as it was in other countries. This finding is also shown in Tables 2 and 3, but the difference was also significant in the final model.

\section{Discussion}

This study adapted and developed a social ecological model for problem gambling and it is the first cross-national study to use a social ecological approach in analyzing problem gambling. This theoretical effort continues the search for more comprehensive frameworks in gambling research that also acknowledge social psychological and environmental factors [29-31]. We focused our article on the Internet as an emerging context for gambling among young people. We found that the social ecological model was useful in investigations of problem gambling, and our results were generally consistent across samples drawn from societies that are socially and culturally very different: the United States, South Korea, Spain, and Finland.

For the purposes of this study, different social ecological systems were analyzed as spheres, and we expected that intrapersonal, interpersonal, and organizational factors would be associated with problem gambling. Measures of organizational and intrapersonal spheres best explained the variance of problem gambling in all four countries. Significant and consistent predictors of problem gambling were online gambling community participation, male gender, and impulsivity. In addition, the interpersonal and societal spheres partly explained problem gambling. Conformity to group norms explained problem gambling in all countries.

Out of all measures the models included in the study, online gambling community participation had the strongest association with problem gambling. Within our study, these communities generally focused on supporting gambling activities, and not discussing potential gambling harm or overcoming gambling problems. Online gambling communities and their social norms hence promote harmful gambling ideas and are a major risk for problem gambling. This finding confirms the results gained in previous empirical research focused on Finland [13]. Other studies focused on gambling and gaming communities and their risks had similar findings, according to a systematic literature review [10]. Our results suggest that recovery-oriented online communities for ex-gamblers and people wishing to decrease or stop their gambling would be important. The benefits of online self-help groups and communities in overcoming problematic behaviors have been noted in other studies [98,99]; however, a challenge is how to make these kinds of communities attractive to young gamblers. Online communities should also be noted in the prevention and treatment of problem gambling, both as a potential risk factor for promoting and reinforcing problematic gambling, and a potential resource for recovery-oriented support.

The findings generally underline similarities across different countries, although problem gambling per se was less common in South Korea. The gender difference was bigger in Spain compared to other countries. The Spanish sample also had the highest rate of problem gambling. The role of impulsivity was less significant in South Korea and not statistically significant in the full model. Furthermore, exposure to pop-up gambling advertisements was not statistically significant among Finnish participants who also had very high exposure to such advertisements. Gambling advertising has been previously considered as aggressive in Finland, which might explain this finding [100]. Additionally, unlicensed gambling providers commonly advertise their services [101]. There were also some differences in country-specific results in the interpersonal sphere. Within the final model, the interpersonal sphere's role was smaller. However, in Finland and South Korea, conformity to group norms was notably associated with problem gambling. However, the effect size was rather small. Despite these differences, our main result was that there were considerable similarities between countries, especially when investigating young people's online behavior. Previous cross-national studies on youth online behavior have also noted that similar factors play a role in online risk factors, despite major cultural and societal differences [14]. 
Our results have practical implications. The results indicated several issues that could be regulated with policies, such as consumer debt, online casinos, and online advertisements. Payday loans and other short-term loans have been under serious discussion in countries such as Finland, where they pose a major risk for young people [38,52]. Online casinos have raised concern because they offer relatively easy access to gambling activities, in particular for younger people [9]. National strategies on regulating online casinos and gambling advertising differ significantly even within the EU. Bypassing restrictions and accessing offshore online casinos is also relatively easy [102]. Previous studies also call for new evidence and policies on regulating gambling advertising [56].

Within our study, we observed major differences in rates of young people accessing online casinos (e.g., Finland $42 \%$ vs. South Korea $8 \%$ ). In South Korea, casino participation was rare compared to the other countries, and it was not a significant predictor of gambling problems. South Korea differs from other investigated countries with its stricter legislation, and hence, our results suggest strict laws might be an effective way to protect young people from gambling harm. Similarly, South Korean young people within our data saw fewer online pop-up gambling advertisements on a weekly basis (13\%) than young people from Spain (38\%), Finland (31\%), and the United States (19\%). These exposure rates, especially in Spain and Finland, are very high and indicate a need to find ways to regulate gambling marketing better.

Additionally, more attention should be paid to the online context and especially to online gambling communities. These communities could also be noted in gambling harm prevention. Other implications are related to better regulation of offshore casinos, illicit gambling advertising, and the availability of payday loans, but these are also related to national and international regulations. As the current online world sets quite a lot of challenges that are sometimes even difficult to tackle, it is crucial to find ways to support young people's wellbeing. Our results also gave statistically significant results on the protective role of perceived social support and social belonging to significant others offline.

This study's findings are limited to the four countries investigated with a crosssectional design. The study is also limited by self-reported information that is potentially sensitive to social desirability bias when asking about problem gambling [103]. It is also likely that individuals with gambling problems are over-represented in online panels compared to the population estimates of problem gambling [87]. Longitudinal and experimental designs should be used in future studies to confirm our results. Moreover, the study's measures were not designed solely for the purposes of the social ecological model, although we were able to use a wide range of measures to help understand personal, interpersonal, organizational, and societal factors. Future studies should continue using the social ecological model to examine problem gambling. They also should continue looking at contextual measures in different levels from the individual to societal. Measures on the actual gambling context could be especially useful. Future studies should also continue investigating the role of the online context and the emerging online risks in gambling behavior.

\section{Conclusions}

This cross-national study's findings underline the benefits of the social ecological model in understanding and tackling problem gambling behavior. The results indicate the importance of the online digital infrastructure's influence on gambling behavior. In our study, online gambling communities, online casinos, and pop-up gambling advertising, as well as fast access to financial resources such as payday loans, were associated with problem gambling. As a phenomenon, problem gambling is relatively similar in the countries representing Europe, North America, and Asia in this study. All countries have to tackle the emerging issues related to online gambling. The social ecological model would be useful in future studies on problem gambling. 
Author Contributions: Conceptualization, A.O.; methodology, A.O., A.K., M.K. and I.V.; software, A.O.; validation, A.O., A.S., M.K., I.S., H.-J.P. and I.Z.; formal analysis, A.O.; investigation, A.O., M.K., A.S. and I.S.; resources, A.O., A.S., I.S. and M.K.; data curation, A.O., A.S., M.K., I.S., H.-J.P. and I.Z.; writing-original draft preparation, A.O., A.S., I.S., A.K., M.K., I.V., I.Z. and H.-J.P.; writing-review and editing, A.O., A.S., I.S., A.K., M.K., I.V., I.Z. and H.-J.P.; visualization, A.O.; supervision, A.O.; project administration, A.O.; and funding acquisition, A.O., A.S., I.S. and M.K. All authors have read and agreed to the published version of the manuscript.

Funding: The Finnish Foundation for Alcohol Studies, Problem Gambling, and Social Media Project 2017-2020 funded this research. PI: Professor Atte Oksanen.

Institutional Review Board Statement: The study was conducted according to the guidelines of the Declaration of Helsinki. The Tampere region ethics committee reviewed the research protocol before implementation and stated that the research did not involve any ethical issues (Decision 62/2016).

Informed Consent Statement: Informed consent was obtained from all subjects involved in the study.

Data Availability Statement: YouGamble 2017-Finnish Data are publicly available in the Finnish Social Science Data Archive (http:/ / urn.fi/urn:nbn:fi:fsd:T-FSD3399) (accessed on 19 March 2021). Data from the United States, South Korea, and Spain will be made publicly available in the Finnish Social Science Data Archive during 2021. The data are available from the corresponding author (A.O.) with a reasonable request.

Conflicts of Interest: The authors declare no conflict of interest. The funder had no role in the study's design, data collection, analyses, data interpretation, manuscript writing, or the decision to publish the results.

\section{Appendix A}

Table A1. Descriptive statistics of the study participants.

\begin{tabular}{ccccc}
\hline & Finland & United States & South Korea & Spain \\
\hline Age (mean) & 21.29 & 20.05 & 20.61 & 20.07 \\
Male (\%) & 50.00 & 49.83 & 49.58 & 51.24 \\
University degree (\%) & 13.42 & 20.38 & 28.1 & 28.38 \\
Occupational status & & & & \\
Student (\%) & 64.33 & 53.96 & 67.53 & 58.33 \\
Working (\%) & 20.33 & 34.16 & 21.82 & 31.36 \\
Unemployed/other (\%) & 15.34 & 11.88 & 10.65 & 10.31 \\
Born abroad (\%) & 4.08 & 4.54 & 0.59 & 12.21 \\
Lives with parents (\%) & 35.92 & 51.16 & 81.80 & 66.67 \\
Significant financial & & & & \\
support from parents or & 17.56 & 35.47 & 65.90 & 58.42 \\
relatives (\%) & & & & \\
\hline
\end{tabular}

Note. * this question was asked only those not living with parents. The exact question was: "how significant of a portion of your average monthly income is financial support provided by your parents or other relatives?".

\section{Appendix B}

Table A2. Alternative linear, logistic, and zero-inflated negative binomial regression models predicting gambling problems.

\begin{tabular}{|c|c|c|c|c|c|c|c|c|c|c|}
\hline & \multicolumn{2}{|c|}{ Linear } & \multicolumn{4}{|c|}{ Logistic } & \multicolumn{4}{|c|}{ ZINB } \\
\hline & $\beta$ & $p$ & OR & $95 \%$ & CI & $p$ & IRR & $95 \%$ & CI & $p$ \\
\hline \multicolumn{11}{|l|}{ Intrapersonal } \\
\hline Male gender & 0.11 & $<0.001$ & 1.96 & 1.36 & 2.82 & $<0.001$ & 1.30 & 1.20 & 1.40 & $<0.001$ \\
\hline Age & 0.02 & 0.145 & 1.01 & 0.95 & 1.07 & 0.725 & 0.99 & 0.97 & 1.00 & 0.039 \\
\hline Impulsivity & 0.10 & $<0.001$ & 1.33 & 1.19 & 1.48 & $<0.001$ & 1.08 & 1.06 & 1.11 & $<0.001$ \\
\hline Self-esteem & -0.03 & 0.042 & 0.90 & 0.82 & 0.99 & 0.030 & 0.97 & 0.95 & 0.99 & 0.005 \\
\hline Risk-taking & 0.08 & $<0.001$ & 1.07 & 0.99 & 1.17 & 0.099 & 1.03 & 1.01 & 1.04 & 0.007 \\
\hline Interpersonal & & & & & & & & & & \\
\hline Perceived social support (high) & -0.07 & $<0.001$ & 0.70 & 0.47 & 1.04 & 0.076 & 0.90 & 0.82 & 0.98 & 0.018 \\
\hline
\end{tabular}


Table A2. Cont.

\begin{tabular}{|c|c|c|c|c|c|c|c|c|c|c|}
\hline & \multicolumn{2}{|c|}{ Linear } & \multicolumn{4}{|c|}{ Logistic } & \multicolumn{4}{|c|}{ ZINB } \\
\hline & $\beta$ & $p$ & OR & $95 \%$ & CI & $p$ & IRR & $95 \%$ & CI & $p$ \\
\hline Belonging offline & -0.02 & 0.178 & 0.91 & 0.81 & 1.01 & 0.080 & 0.96 & 0.94 & 0.99 & 0.004 \\
\hline Belonging online & 0.03 & 0.052 & 1.08 & 0.99 & 1.17 & 0.068 & 1.02 & 1.00 & 1.04 & 0.013 \\
\hline Social media identity bubble & 0.03 & 0.029 & 1.13 & 1.01 & 1.26 & 0.035 & 1.02 & 1.00 & 1.05 & 0.074 \\
\hline $\begin{array}{c}\text { Conformity to group norm } \\
\text { Organizational }\end{array}$ & 0.04 & $<0.001$ & 1.08 & 0.92 & 1.27 & 0.349 & 1.04 & 1.01 & 1.08 & 0.016 \\
\hline Consumer debt & 0.11 & $<0.001$ & 2.91 & 2.00 & 4.23 & $<0.001$ & 1.23 & 1.11 & 1.36 & $<0.001$ \\
\hline Online casino participation & 0.22 & $<0.001$ & 2.56 & 1.58 & 4.14 & $<0.001$ & 1.20 & 1.09 & 1.32 & $<0.001$ \\
\hline $\begin{array}{l}\text { Online gambling comm. partic. } \\
\text { Pop-up gambling adv. (ref. never) }\end{array}$ & 0.28 & $<0.001$ & 2.68 & 1.70 & 4.20 & $<0.001$ & 1.39 & 1.26 & 1.54 & $<0.001$ \\
\hline Max monthly & 0.03 & 0.014 & 1.39 & 0.67 & 2.90 & 0.381 & 1.02 & 0.88 & 1.19 & 0.748 \\
\hline $\begin{array}{l}\text { Weekly } \\
\text { Societal }\end{array}$ & 0.09 & $<0.001$ & 2.41 & 1.13 & 5.14 & 0.022 & 1.17 & 1.00 & 1.36 & 0.047 \\
\hline $\begin{array}{c}\text { Country difference (ref. Spain) } \\
\text { Finland }\end{array}$ & 0.00 & 0.929 & 0.76 & 0.48 & 1.20 & 0.237 & 1.06 & 0.94 & 1.18 & 0.348 \\
\hline The U.S. & -0.05 & 0.003 & 0.80 & 0.52 & 1.22 & 0.295 & 0.90 & 0.79 & 1.03 & 0.135 \\
\hline South Korea & -0.06 & $<0.001$ & 0.66 & 0.38 & 1.13 & 0.132 & 1.07 & 0.97 & 1.18 & 0.195 \\
\hline Model N & $4546 *$ & & 4816 & & & & 4816 & & & \\
\hline Adjusted $\mathrm{R}^{2}$ & $38 \%$ & & & & & & & & & \\
\hline Pseudo adj. $\mathrm{R}^{2}$ (McFadden) & & & $24 \%$ & & & & $42 \%$ & & & \\
\hline
\end{tabular}

Note. ${ }^{*}$ Outliers omitted from the linear regression model.

\section{References}

1. Calado, F.; Griffiths, M.D. Problem gambling worldwide: An update and systematic review of empirical research (2000-2015). J. Behav. Addict. 2016, 5, 592-613. [CrossRef] [PubMed]

2. Calado, F.; Alexandre, J.; Griffiths, M.D. Prevalence of adolescent problem gambling: A systematic review of recent research. J. Gambl. Stud. 2017, 33, 397-424. [CrossRef]

3. Volberg, R.; Gupta, R.; Griffiths, M.D.; Olason, D.; Delfabbro, P.H. An international perspective on youth gambling prevalence studies. Int. J. Adolesc. Med. Health 2010, 22, 3-38. [CrossRef]

4. Blaszczynski, A.; Nower, L. A pathways model of problem and pathological gambling. Addiction 2002, 97, 487-499. [CrossRef] [PubMed]

5. Goudriaan, A.E.; Slutske, W.S.; Krull, J.L.; Sher, K.J. Longitudinal patterns of gambling activities and associated risk factors in college students. Addiction 2009, 104, 1219-1232. [CrossRef]

6. Livazović, G.; Bojčić, K. Problem gambling in adolescents: What are the psychological, social and financial consequences? BMC Psychiatry 2019, 19, 1-15. [CrossRef]

7. Delfabbro, P. Problem and pathological gambling: A conceptual review. J. Gambl. Bus. Econ. 2013, 7, 35-53. [CrossRef]

8. Gainsbury, S.M.; Russell, A.; Wood, R.; Hing, N.; Blaszczynski, A. How risky is Internet gambling? A comparison of subgroups of Internet gamblers based on problem gambling status. New Media Soc. 2015, 17, 861-879. [CrossRef]

9. King, D.L.; Delfabbro, P.H. Early exposure to digital simulated gambling: A review and conceptual model. Comput. Hum. Behav. 2016, 55, 198-206. [CrossRef]

10. Sirola, A.; Savela, N.; Savolainen, I.; Kaakinen, M.; Oksanen, A. The Role of Virtual Communities in Gambling and Gaming Behaviors: A Systematic Review. J. Gambl. Stud. 2020. [CrossRef]

11. Kaakinen, M.; Sirola, A.; Savolainen, I.; Oksanen, A. Young people and gambling content in social media: An experimental insight. Drug Alcohol Rev. 2020, 39, 152-161. [CrossRef]

12. King, D.L.; Delfabbro, P.H.; Kaptsis, D.; Zwaans, T. Adolescent simulated gambling via digital and social media: An emerging problem. Comput. Hum. Behav. 2014, 31, 305-313. [CrossRef]

13. Sirola, A.; Kaakinen, M.; Oksanen, A. Excessive gambling and online gambling communities. J. Gambl. Stud. 2018, 34, 1313-1325. [CrossRef]

14. Keipi, T.; Näsi, M.; Oksanen, A.; Räsänen, P. Online Hate and Harmful Content: Cross-National Perspectives; Routledge: New York, NY, USA, 2017. [CrossRef]

15. Lewin, K. A Dynamic Theory of Personality. Selected Papers; McGraw-Hill: New York, NY, USA, 1935; p. 73.

16. Bronfenbrenner, U. The Ecology of Human Development; Harvard University Press: Harvard, MA, USA, 1979.

17. Bronfenbrenner, U. Ecological systems theory. In Six Theories of Child Development: Revised Formulations and Current Issues; Vasta, R., Ed.; Jessica Kingsley Publishers: London, UK, 1992; pp. 187-249.

18. Bronfenbrenner, U. Making Human Beings Human: Bioecological Perspectives on Human Development; Sage: London, UK, 2005.

19. Bronfenbrenner, U. Ecological models of human development. Read. Dev. Child. 1994, 2, 37-43.

20. Stokols, D. Establishing and maintaining healthy environments: Toward a social ecology of health promotion. Am. Psychol. 1992, 47, 6-22. [CrossRef] 
21. Chan, G.C.; Stjepanović, D.; Lim, C.; Sun, T.; Anandan, A.S.; Connor, J.P.; Gartner, C.; Hall, W.D.; Leung, J. Gateway or common liability? A systematic review and meta-analysis of studies of adolescent e-cigarette use and future smoking initiation. Addiction 2020. [CrossRef]

22. Gruenewald, P.J.; Remer, L.G.; LaScala, E.A. Testing a social ecological model of alcohol use: The California 50-city study. Addiction 2014, 109, 736-745. [CrossRef]

23. Paek, H.-J.; Hove, T. Determinants of underage college student drinking: Implications for four major alcohol reduction strategies. J. Health Commun. 2012, 17, 659-676. [CrossRef] [PubMed]

24. Mayberry, M.L.; Espelage, D.L.; Koenig, B. Multilevel modeling of direct effects and interactions of peers, parents, school, and community influences on adolescent substance use. J. Youth Adolesc. 2009, 38, 1038-1049. [CrossRef]

25. Connell, C.M.; Gilreath, T.D.; Aklin, W.M.; Brex, R.A. Social-ecological influences on patterns of substance use among nonmetropolitan high school students. Am. J. Community Psychol. 2020, 45, 36-48. [CrossRef]

26. Thompson, J.R.; Creasy, S.L.; Mair, C.F.; Burke, J.G. Drivers of opioid use in Appalachian Pennsylvania: Cross-cutting social and community-level factors. Int. J. Drug Policy. 2020, 78, 102706. [CrossRef]

27. Baral, S.; Logie, C.H.; Grosso, A.; Wirtz, A.L.; Beyrer, C. Modified social ecological model: A tool to guide the assessment of the risks and risk contexts of HIV epidemics. BMC Public Health 2013, 13, 1-8. [CrossRef]

28. Cross, D.; Barnes, A.; Papageorgiou, A.; Hadwen, K.; Hearn, L.; Lester, L. A social-ecological framework for understanding and reducing cyberbullying behaviours. Aggress. Violent Behav. 2015, 23, 109-117. [CrossRef]

29. Abbott, M.; Binde, P.; Clark, L.; Hodgins, D.; Korn, D.; Pereira, A.; Quilty, L.; Thomas, A.; Volberg, R.; Walker, D.; et al. Conceptual Framework of Harmful Gambling: An International Collaboration Revised Edition; Gambling Research Exchange Ontario (GREO): Guelph, ON, Canada, 2015. [CrossRef]

30. Hilbrecht, M.; Baxter, D.; Abbott, M.; Binde, P.; Clark, L.; Hodgins, D.C.; Manitowabi, D.; Quilty, L.; SpÅngberg, J.; Volberg, R.; et al. The Conceptual Framework of Harmful Gambling: A revised framework for understanding gambling harm. J. Behav. Addict. 2020, 9, 190-205. [CrossRef] [PubMed]

31. Reith, G. Beyond addiction or compulsion: The continuing role of environment in the case of pathological gambling. Addiction 2012, 107, 1736-1737. [CrossRef]

32. Orford, J. Excessive Appetites: A Psychological View of Addictions, 2nd ed.; Wiley: Chichester, UK, 2001.

33. West, R.; Brown, J. Theory of Addiction, 2nd ed.; Wiley: Chichester, UK, 2013. [CrossRef]

34. Oksanen, A. Deleuze and the theory of addiction. J. Psychoact. Drugs 2013, 45, 57-67. [CrossRef]

35. Dowling, N.A.; Merkouris, S.S.; Greenwood, C.J.; Oldenhof, E.; Toumbourou, J.W.; Youssef, G.J. Early risk and protective factors for problem gambling: A systematic review and meta-analysis of longitudinal studies. Clin. Psychol. Rev. 2017, 51, 109-124. [CrossRef] [PubMed]

36. Dussault, F.; Brendgen, M.; Vitaro, F.; Wanner, B.; Tremblay, R.E. Longitudinal links between impulsivity, gambling problems and depressive symptoms: A transactional model from adolescence to early adulthood. J. Child. Psychol. Psychiatry 2011, 52, 130-138. [CrossRef]

37. Slutske, W.S.; Caspi, A.; Moffitt, T.E.; Poulton, R. Personality and problem gambling: A prospective study of a birth cohort of young adults. Arch. Gen. Psychiatry 2005, 62, 769-775. [CrossRef] [PubMed]

38. Oksanen, A.; Aaltonen, M.; Majamaa, K.; Rantala, K. Debt problems, home-leaving, and boomeranging: A register-based perspective on economic consequences of moving away from parental home. Int. J. Consum. Stud. 2017, 41, 340-352. [CrossRef]

39. Worthy, S.L.; Jonkman, J.; Blinn-Pike, L. Sensation-seeking, risk-taking, and problematic financial behaviors of college students. J. Fam. Econ. Issues 2010, 31, 161-170. [CrossRef]

40. Blinn-Pike, L.; Worthy, S.L.; Jonkman, J.N. Adolescent gambling: A review of an emerging field of research. J. Adolesc. Health 2010, 47, 223-236. [CrossRef] [PubMed]

41. Canale, N.; Vieno, A.; Lenzi, M.; Griffiths, M.D.; Borraccino, A.; Lazzeri, G.; Lemma, P.; Scacchi, L.; Santinello, M. Income inequality and adolescent gambling severity: Findings from a large-scale Italian representative survey. Front. Psychol. 2017, 8, 1318. [CrossRef]

42. Hardoon, K.K.; Gupta, R.; Derevensky, J.L. Psychosocial variables associated with adolescent gambling. Psychol. Addict. Behav. 2004, 18, 170-179. [CrossRef]

43. Petry, N.M.; Weiss, L. Social support is associated with gambling treatment outcomes in pathological gamblers. Am. J. Addict. 2009, 18, 402-408. [CrossRef] [PubMed]

44. Elgar, F.J.; Canale, N.; Wohl, M.J.; Lenzi, M.; Vieno, A. Relative deprivation and disordered gambling in youths. J. Epidemiol. Community Health 2018, 72, 589-594. [CrossRef] [PubMed]

45. Molinaro, S.; Canale, N.; Vieno, A.; Lenzi, M.; Siciliano, V.; Gori, M.; Santinello, M. Country-and individual-level determinants of probable problematic gambling in adolescence: A multi-level cross-national comparison. Addiction 2014, 109, $2089-2097$. [CrossRef]

46. Molinaro, S.; Benedetti, E.; Scalese, M.; Bastiani, L.; Fortunato, L.; Cerrai, S.; Canale, N.; Chomynova, P.; Elekes, Z.; Feijão, F.; et al. Prevalence of youth gambling and potential influence of substance use and other risk factors throughout 33 European countries: First results from the 2015 ESPAD study. Addiction 2018, 113, 1862-1873. [CrossRef]

47. Savolainen, I.; Sirola, A.; Kaakinen, M.; Oksanen, A. Peer group identification as determinant of youth behavior and the role of perceived social support in problem gambling. J. Gambl. Stud. 2019, 35, 15-30. [CrossRef] 
48. Kaakinen, M.; Sirola, A.; Savolainen, I.; Oksanen, A. Shared identity and shared information in social media: Development and validation of the identity bubble reinforcement scale. Media Psychol. 2020, 23, 25-51. [CrossRef]

49. Savolainen, I.; Kaakinen, M.; Sirola, A.; Koivula, A.; Hagfors, H.; Zych, I.; Paek, H.-J.; Oksanen, A. Online Relationships and Social Media Interaction in Youth Problem Gambling: A Four-Country Study. Int. J. Environ. Res. Public Health 2020, $17,8133$. [CrossRef]

50. Meisel, M.K.; Goodie, A.S. Descriptive and injunctive social norms' interactive role in gambling behavior. Psychol. Addict. Behav. 2014, 28, 592-598. [CrossRef]

51. Derevensky, J.L.; Gainsbury, S.M. Social casino gaming and adolescents: Should we be concerned and is regulation in sight? Int. J. Law Psychiatry 2016, 44, 1-6. [CrossRef] [PubMed]

52. Oksanen, A.; Savolainen, I.; Sirola, A.; Kaakinen, M. Problem gambling and psychological distress: A cross-national perspective on the mediating effect of consumer debt and debt problems among emerging adults. Harm Reduct. J. 2018, 15, 45. [CrossRef]

53. Håkansson, A.; Widinghoff, C. Over-Indebtedness and Problem Gambling in a General Population Sample of Online Gamblers. Front. Psychiatry 2020, 11. [CrossRef]

54. Abarbanel, B.; Gainsbury, S.M.; King, D.; Hing, N.; Delfabbro, P.H. Gambling games on social platforms: How do advertisements for social casino games target young adults? Policy Internet 2017, 9, 184-209. [CrossRef]

55. Binde, P. Gambling Advertising: A Critical Research Review; Responsible Gambling Trust: London, UK, 2014.

56. Parke, A.; Harris, A.; Parke, J.; Rigbye, J.; Blaszczynski, A. Responsible marketing and advertising in gambling: A critical review. J. Gambl. Bus. Econ. 2014, 8, 21-35. [CrossRef]

57. Newall, P.W.; Moodie, C.; Reith, G.; Stead, M.; Critchlow, N.; Morgan, A.; Dobbie, F. Gambling marketing from 2014 to 2018: A literature review. Curr. Addict. Rep. 2019, 6, 49-56. [CrossRef]

58. Russell, A.M.; Hing, N.; Browne, M.; Rawat, V. Are direct messages (texts and emails) from wagering operators associated with betting intention and behavior? An ecological momentary assessment study. J. Behav. Addict. 2018, 7, 1079-1090. [CrossRef]

59. Williams, R.J.; Lee, C.K.; Back, K.J. The prevalence and nature of gambling and problem gambling in South Korea. Soc. Psychiatry Psychiatr. Epidemiol. 2013, 48, 821-834. [CrossRef] [PubMed]

60. King, D.L.; Russell, A.; Hing, N. Adolescent Land-Based and Internet Gambling: Australian and International Prevalence Rates and Measurement Issues. Curr. Addict. Rep. 2020, 7, 137-148. [CrossRef]

61. ESPAD Group. ESPAD Report 2019: Results from the European School Survey Project on Alcohol and Other Drugs; EMCDDA Joint Publications, Publications Office of the European Union: Luxembourg, 2020. Available online: http://www.espad.org/sites/ espad.org/files/2020.3878_EN_04.pdf (accessed on 19 March 2021).

62. Esping-Andersen, G. The Three Worlds of Welfare Capitalism; Polity Press: Cambridge, UK, 1990; ISBN 0-7456-0665-2.

63. Ferrera, M. The 'Southern model' of welfare in social Europe. J. Eur. Soc. Policy 1996, 6, 17-37. [CrossRef]

64. World Value Survey. The Inglehart-Welzel World Cultural Map-World Values Survey 7. [Provisional Version]. 2020. Available online: http:/ / www.worldvaluessurvey.org/ (accessed on 27 January 2021).

65. Inglehart, R. Cultural Evolution: People's Motivations Are Changing, and Reshaping the World; Cambridge University Press: Cambridge, UK, 2018. [CrossRef]

66. Suh, E.; Diener, E.; Oishi, S.; Triandis, H.C. The shifting basis of life satisfaction judgments across cultures: Emotions versus norms. J. Pers. Soc. Psychol. 1998, 74, 482. [CrossRef]

67. Triandis, H. Collectivism and Individualism: Cultural and Psychological Concerns. In International Encyclopedia of the Social E Behavioral Sciences, 2nd ed.; Elsevier: Amsterdam, The Netherlands, 2015; Volume 4, pp. 206-210. [CrossRef]

68. Sirola, A.; Kaakinen, M.; Savolainen, I.; Paek, H.J.; Zych, I.; Oksanen, A. Online Identities and Social Influence in Social Media Gambling Exposure: A Four-Country Study on Young People. Telemat. Inform. 2021, 60. [CrossRef]

69. Welte, J.W.; Barnes, G.M.; Tidwell, M.C.; Hoffman, J.H.; Wieczorek, W.F. Gambling and Problem Gambling in the United States: Changes Between 1999 and 2013. J. Gambl. Stud. 2015, 31, 695-715. [CrossRef]

70. Tammi, T.; Castrén, S.; Lintonen, T. Gambling in Finland: Problem gambling in the context of a national monopoly in the European Union. Addiction 2015, 110, 746-750. [CrossRef] [PubMed]

71. Jiménez-Murcia, S.; Fernández-Aranda, F.; Granero, R.; Menchón, J.M. Gambling in Spain: Update on experience, research and policy. Addiction 2014, 109, 1595-1601. [CrossRef]

72. Kang, K.; Ok, J.S.; Kim, H.; Lee, K.S. The Gambling Factors Related with the Level of Adolescent Problem Gambler. Int. J. Environ. Res. Public Health 2019, 16, 2110. [CrossRef]

73. Williams, R.J.; Volberg, R.A.; Stevens, R.M.G. The Population Prevalence of Problem Gambling: Methodological Influences, Standardized Rates, Jurisdictional Differences, and Worldwide Trends. 2012. Available online: https://hdl.handle.net/10133/30 68 (accessed on 19 March 2021).

74. Salonen, A.; Lind, K.; Hagfors, H.; Castrén, S.; Kontto, J. Rahapelaaminen, Peliongelmat ja Rahapelaamiseen Liittyvät Asenteet ja Mielipiteet Vuosina 2007-2019: Suomalaisten Rahapelaaminen 2019; Finnish Institute for Health and Welfare: Helsinki, Finland, 2020; ISBN 978-952-343-594-0.

75. Spanish Observatory of Drugs and Addictions and Government Delegation for the National Drugs Plan. Adicciones Comportamentales; Ministerio de Sanidad: Madrid, Spain, 2019. Available online: https://pnsd.sanidad.gob.es/eu/profesionales/ sistemasInformacion/sistemaInformacion/pdf/2019_Informe_adicciones_comportamentales_2.pdf (accessed on 19 March 2021). 
76. Chóliz, M.; Lamas, J. ¡ Hagan juego, menores! Frecuencia de juego en menores de edad y su relación con indicadores de adicción al juego. Rev. Esp. Drogodepend. 2017, 42, 34-47.

77. Gómez Yáñez, J.A.; Lalanda Fernández, C. Anuario del Juego en España 2020; Instituto de Política y Gobernanza de la Universidad Carlos III y CEJUEGO: Madrid, Spain, 2020. Available online: http:/ / cejuego.com/documentacion/files/Anuario\%20del\%20 Juego\%20en\%20Espa\%C3\%B1a\%202020.pdf (accessed on 27 January 2021).

78. González-Roz, A.; Fernández-Hermida, J.R.; Weidberg, S.; Martínez-Loredo, V.; Secades-Villa, R. Prevalence of Problem Gambling among Adolescents: A Comparison across Modes of Access, Gambling Activities, and Levels of Severity. J. Gambl. Stud. 2017, 33, 371-382. [CrossRef] [PubMed]

79. Nowak, D.E.; Aloe, A.M. The prevalence of pathological gambling among college students: A meta-analytic synthesis, 2005-2013. J. Gambl. Stud. 2014, 30, 819-843. [CrossRef]

80. Jang, S.M.; Hong, S.; Kim, S.B.; Sohn, S. Examining risk and protective factors of problem gambling among college students in South Korea. Child. Youth Serv. Rev. 2019, 105, 104418. [CrossRef]

81. Jang, S.M. Structural analysis on the path of problem gambling among college students: Using Jacob's general theory of addiction. Korean J. Soc. Welf. 2013, 65, 231-254. [CrossRef]

82. Park, S.; Cho, M.J.; Jeon, H.J.; Lee, H.W.; Bae, J.N.; Park, J.I.; Sohn, J.H.; Lee, Y.R.; Lee, J.Y.; Hong, J.P. Prevalence, clinical correlations, comorbidities, and suicidal tendencies in pathological Korean gamblers: Results from the Korean Epidemiologic Catchment Area Study. Soc. Psychiatry Psychiatr. Epidemiol. 2010, 45, 621-629. [CrossRef] [PubMed]

83. Lehdonvirta, V.; Oksanen, A.; Räsänen, P.; Blank, G. Social media, web, and panel surveys: Using non-probability samples in social and policy research. Policy Internet 2020. [CrossRef]

84. Oksanen, A.; Sirola, A.; Savolainen, I.; Kaakinen, M. Gambling patterns and associated risk and protective factors among Finnish young people. Nord. Stud. Alcohol Drugs 2019, 36, 161-176. [CrossRef] [PubMed]

85. Curran, P.G. Methods for the detection of carelessly invalid responses in survey data. J. Exp. Soc. Psychol. 2016, 66, 4-19. [CrossRef]

86. Pickering, D.; Blaszczynski, A. Paid online convenience samples in gambling studies: Questionable data quality. Int. Gambl. Stud. 2021. [CrossRef]

87. Lesieur, H.R.; Blume, S.B. The South Oaks Gambling Screen (SOGS): A new instrument for the identification of pathological gamblers. Am. J. Psychiatry 1987, 144. [CrossRef]

88. Grigsby, T. Substance and Behavioral Addictions Assessment Instruments. In The Cambridge Handbook of Substance and Behavioral Addictions; Sussman, S., Ed.; Cambridge University Press: Cambridge, UK, 2020; pp. 87-105. [CrossRef]

89. Castrén, S.; Kontto, J.; Alho, H.; Salonen, A.H. The relationship between gambling expenditure, socio-demographics, healthrelated correlates and gambling behaviour-A cross-sectional population-based survey in Finland. Addiction 2018, 113, 91-106. [CrossRef]

90. Salonen, A.H.; Alho, H.; Castrén, S. Attitudes towards gambling, gambling participation, and gambling-related harm: Crosssectional Finnish population studies in 2011 and 2015. BMC Public Health 2017, 17, 1-11. [CrossRef] [PubMed]

91. Goodie, A.S.; MacKillop, J.; Miller, J.D.; Fortune, E.E.; Maples, J.; Lance, C.E.; Campbell, W.K. Evaluating the South Oaks Gambling Screen with DSM-IV and DSM-5 criteria: Results from a diverse community sample of gamblers. Assessment 2013, 20, 523-531. [CrossRef] [PubMed]

92. Eysenck, S.B.G.; Eysenck, H.J. Impulsiveness and Venturesomeness: Their Position in a Dimensional System of Personality Description. Psychol. Rep. 1978, 43, 1247-1255. [CrossRef]

93. Robins, R.W.; Hendin, H.M.; Trzesniewski, K.H. Measuring global self-esteem: Construct validation of a single-item measure and the Rosenberg Self-Esteem Scale. Pers. Soc. Psychol. Bull. 2001, 27, 151-161. [CrossRef]

94. NLSY79 Children \& Young Adults. NLSY79 Child \& Young Adults Data Users Guide; Center for Human Resource Research, The Ohio State University: Columbus, OH, USA, 2009. Available online: https://www.nlsinfo.org/pub/usersvc/Child-YoungAdult/2006ChildYA-DataUsersGuide.pdf (accessed on 27 January 2021).

95. Harden, K.P.; Tucker-Drob, E.M. Individual differences in the development of sensation seeking and impulsivity during adolescence: Further evidence for a dual systems model. Dev. Psychol. 2011, 47, 739-746. [CrossRef]

96. Yang, S.; Harlow, L.L.; Puggioni, G.; Redding, C.A. A comparison of different methods of zero-inflated data analysis and an application in health surveys. J. Mod. Appl. Stat. Methods 2017, 16, 518-543. [CrossRef]

97. Cameron, A.C.; Trivedi, P.K. Regression Analysis of Count Data, 2nd ed.; Cambridge University Press: Cambridge, UK, 2013 ; p. 85. [CrossRef]

98. Barak, A.; Boniel-Nissim, M.; Suler, J. Fostering empowerment in online support groups. Comput. Hum. Behav. 2008, 24, 1867-1883. [CrossRef]

99. Wood, R.T.; Wood, S.A. An evaluation of two United Kingdom online support forums designed to help people with gambling issues. J. Gambl. Issues 2009, 23, 5-30. [CrossRef]

100. Castren, S.; Murto, A.; Salonen, A. Rahapelimarkkinointi yhä aggressiivisempaa-unohtuvatko hyvät periaatteet? Yhteiskuntapolitiikka 2014, 79, 438-443. Available online: http:/ / urn.fi/URN:NBN:fi-fe2014090444492 (accessed on 19 March 2021).

101. Littler, A.; Jarvinen-Tassopoulos, J. Online Gambling, Regulation, and Risks: A Comparison of Gambling Policies in Finland and the Netherlands. J. Law Soc. Policy 2018, 30, 100-126. Available online: https:/ /digitalcommons.osgoode.yorku.ca/jlsp/vol30/ iss1/ 6 (accessed on 19 March 2021). 
102. Hörnle, J.; Littler, A.; Tyson, G.; Padumadasa, E.; Schimidt-Kessen, M.J.; Ibosiola, D.I. Evaluation of Regulatory Tools for Enforcing Online Gambling Rules and Channelling Demand towards Controlled Offers; European Commission: Brussels, Belgium, 2018. Available online: https://op.europa.eu/en/publication-detail/-/publication/6bac835f-2442-11e9-8d04-01aa75ed71a1 /language-en (accessed on 19 March 2021).

103. Kuentzel, J.G.; Henderson, M.J.; Melville, C.L. The impact of social desirability biases on self-report among college student and problem gamblers. J. Gambl. Stud. 2008, 24, 307-319. [CrossRef] [PubMed] 